\title{
Seasonal change of phytoplankton (spring vs. summer) in the southern Patagonian shelf
}

\author{
Rafael Gonçalves-Araujo*, Márcio Silva de Souza, Carlos Rafael Borges Mendes, \\ Virginia Maria Tavano, Carlos A.E. Garcia
}

Instituto de Oceanografia, Universidade Federal do Rio Grande (FURG), Av. Itália, km 8, 96201-900 Rio Grande, RS, Brazil

\section{A R T I C L E I N F O}

\section{Article history:}

Received 20 January 2016

Received in revised form

14 March 2016

Accepted 18 March 2016

Available online 26 March 2016

Keywords:

Southern Patagonian shelf Phytoplankton community

Water column structure

Nutrient concentrations

Seasonal variability

\begin{abstract}
A B S T R A C T
As part of the Patagonian Experiment (PATEX) project two sequential seasons (spring/summer 20072008) were sampled in the southern Patagonian shelf, when physical-chemical-biological (phytoplankton) data were collected. Phytoplankton biomass and community composition were assessed through both microscopic and high-performance liquid chromatography/chemical taxonomy (HPLC) CHEMTAX) techniques and related to both in situ and satellite data at spatial and seasonal scales. Phytoplankton seasonal variation was clearly modulated by water column thermohaline structure and nutrient dynamics [mainly dissolved inorganic nitrogen (DIN) and silicate]. The spring phytoplankton community showed elevated biomass and was dominated by diatoms [mainly Corethron pennatum and small ( $<20 \mu \mathrm{m}$ ) cells of Thalassiosira spp.], associated with a deeper and more weakly stratified upper mixed layer depth (UMLD) and relatively low nutrient concentrations, which were probably a result of consumption by the diatom bloom. In contrast, the phytoplankton community in summer presented lower biomass and was mainly dominated by haptophytes (primarily Emiliania huxleyi and Phaeocystis antarctica) and dinoflagellates, associated with shallower and well-stratified upper mixed layers with higher nutrient concentrations, likely due to lateral advection of nutrient-rich waters from the Malvinas Current. The gradual establishment of a strongly stratified and shallow UMLD as season progressed, was an important factor leading to the replacement of the spring diatom community by a dominance of calcifying organisms, as shown in remote sensing imagery and confirmed by microscopic examination. Furthermore, in spring, phaeopigments $a$ (degradation products of chlorophyll $a$ ) relative to chlorophyll $a$, were twice that of summer, indicating the diatom bloom was under higher grazing pressure.
\end{abstract}

(c) 2016 Elsevier Ltd. All rights reserved.

\section{Introduction}

The southern Patagonian shelf, a region that extends from approximately $47^{\circ} \mathrm{S}$ to the tip of South America (Cape Horn), encompasses a vital ecosystem, recognized as a highly productive area of the SW Atlantic (El-Sayed, 1967; Lutz et al., 2010; Dogliotti et al., 2014). Oceanographic conditions in this region support high biomass of phytoplankton, zooplankton, fish and squid during spring-summer seasons (Cousseau and Perrota, 2000; Sabatini et al., 2000, 2012; Rivas et al., 2006; Lutz et al., 2010, and references therein). In addition, it has been reported that the SW Atlantic is an important $\mathrm{CO}_{2}$ sink area (Bianchi et al., 2005, 2009; Takahashi et al., 2009) and phytoplankton plays a crucial role in

\footnotetext{
* Corresponding author. Current address: Alfred-Wegener-Institut Helmholtz Zentrum für Polar- und Meeresforschung (AWI), Climate Sciences, Physical Oceanography of Polar Seas, Bussestraße 24, F-402, 27570 Bremerhaven, Germany.

E-mail addresses: rafael.goncalves.araujo@awi.de, rafaelgoncalvesaraujo@gmail.com (R. Gonçalves-Araujo).
}

the ocean uptake of atmospheric $\mathrm{CO}_{2}$ in the region (Schloss et al. 2007; Bianchi et al., 2009).

The southern Patagonian shelf is characterized by a complex circulation system, with influence from subantarctic waters, advected from the Malvinas Current (Matano et al., 2010), and the Magellan Strait run-off (Sabatini et al., 2000, 2004). In addition, thermohaline fronts (Sabatini et al., 2004) and a strong tidal regime (Glorioso and Flather, 1997; Glorioso, 2002) play a significant role in biological production, with consequences to ecological processes, involving various trophic levels (Sabatini et al., 2000, 2012; Acha et al., 2004).

Spatial patterns of phytoplankton distribution have been studied along the Patagonian shelf by remote sensing (Gonzalez-Silvera et al., 2006; Signorini et al., 2006; d'Ovidio et al., 2010; Dogliotti et al., 2014) and in situ sampling for phytoplankton composition (Garcia et al., 2008; Painter et al., 2010; de Souza et al., 2012; Segura et al., 2013; Balch et al., 2014). However, there is scarce data on changes in phytoplankton community over consecutive seasons in the region (Segura et al., 2013). Based on time 
series from remote sensing and historic hydrographic data, Signorini et al. (2006) showed that the seasonal variability and succession of phytoplankton groups along the Patagonian shelf-break respond to light intensity and nutrient supply within the mixed layer, driven by seasonal changes in the water column structure: an early spring bloom dominated by diatoms associated with high nutrient levels is replaced by coccolithophore-dominated summer blooms related to shallow upper mixed layer depth (UMLD).

A community co-dominated by diatoms and dinoflagellates, associated with high chlorophyll $a$ (Chl a) levels (up to $20 \mathrm{mg} \mathrm{m}^{-3}$ ), was reported during a spring campaign in 2004; along the Argentinean shelf-break region, where upwelling seemed to be an important source of nutrients (Garcia et al., 2008). Close to our study region, in the southern Patagonian shelf, a diatom-dominated spring assemblage was replaced by prymnesiophytes (e.g. coccolithophores) in late summer during the austral spring/summer season 2005/2006 (Segura et al., 2013). In summer 2008 (same data used in this study) the phytoplankton community was patchily distributed in the southern Patagonian shelf, with dominance of the coccolithophore Emiliania huxleyi and, in some sites, also with a significant contribution of the haptophyte Phaeocystis antarctica and/or dinoflagellates, associated with varying levels of dissolved inorganic nutrients (de Souza et al., 2012). Another study conducted in summer 2008/2009 in the southern Patagonian shelf region depicted a coccolithophore bloom associated with the Subantarctic Shelf Water domain, and many of the commonly cited conditions for coccolithophore bloom development (e.g. low N:P ratio, high $\mathrm{N}: S i$ ratio and shallow mixed layer depth) (Painter et al., 2010). The bloom, which shared dominance with either high numbers of the dinoflagellate Prorocentrum sp. or a mixture of diatoms, dinoflagellates and flagellates, was associated with silicate depletion, probably from a previous diatom bloom (Balch et al., 2014).

Despite the recognized ecological and economical importance of the area and the works previously conducted in the region, the processes modulating phytoplankton community evolution and, for instance, the replacement of major phytoplankton species through spring-summer seasons are still poorly understood. Thus, the present work aims to evaluate changes in the composition of phytoplankton communities from spring to summer and associated bottom-up control factors that may lead to succession of phytoplankton groups in the southern Patagonian shelf region. Two different approaches (microscopy and High Performance Liquid Chromatography-HPLC/CHEMTAX) were applied to identify and quantify the phytoplankton assemblages, and were complemented with remote sensing time series of relevant variables. Hence, this study provides a characterization of the phytoplankton community and, combined with the environmental data set and Chl $a$ degradation products, a more comprehensive assessment is provided on phytoplankton dynamics over the spring to summer seasons in the southern Patagonian Sea, including some insights on the physiological conditions of those assemblages.

\section{Material and methods}

\subsection{Sampling}

The data set in this work was collected during two oceanographic cruises conducted on board the Brazilian Navy R/V "Ary Rongel" along the southern Patagonian shelf, in the context of the Patagonian Experiment (PATEX) project in the area between $48.5^{\circ}$ and $50.5^{\circ} \mathrm{S}$ (Fig. 1). The first cruise was conducted in the austral spring season (21-22 Oct 2007), when 9 stations were occupied and the second cruise in austral summer (04-07 Jan 2008) with 18 stations sampled. The structure of the phytoplankton community and the bio-optical characteristics of a coccolithophore bloom during the summer cruise 2008 have been described in de Souza et al. (2012) and Garcia et al. (2011), respectively. Water samples for biological and chemical analyses were collected using Niskin bottles attached to a combined rosette + CTD SeaBird ${ }^{\circledR} 911$ carrousel system.

\subsection{Physical parameters}

From vertical profiles of temperature and salinity acquired with the CTD casts, the potential density $(\rho)$ was calculated. Upper mixed layer depth (UMLD) was then determined from vertical density profiles $(\partial \rho / \partial z)$ as the depth where variations in density were equal or greater than 0.02 over 5-m depth interval (adapted from Mitchell and Holm-Hansen (1991)).

Water column stability parameter $(E)$ was obtained based on vertical density variations, inferred from the buoyancy or BruntVäisälä frequency $\left(N^{2}\right)$, which is defined by $N^{2}=-\frac{g}{\rho} \frac{\partial \rho}{\partial z}\left(\operatorname{rad}^{2} s^{-2}\right)$ leading to $E=\frac{N^{2}}{g}\left(10^{-8} \mathrm{rad}^{2} \mathrm{~m}^{-1}\right)$, where $g$ is gravity and $\rho$ is the potential water density. In this study, the maximum stability value immediately below the UMLD was considered to represent the strength of the pycnocline (Castro et al., 2002).

Water mass classification was based on an adaptation of the thermohaline intervals found in Bianchi et al. (1982, 2005), Möller et al. (2008) and Painter et al. (2010) (Table 1).

\subsection{Nutrient analysis}

Surface water samples were filtered through cellulose acetate membrane filters to determine dissolved inorganic nutrients (DIN: nitrate, nitrite and ammonium; phosphate and silicate). Nutrients were analyzed on board, following the recommendations in Aminot and Chaussepied (1983), and absorbance values were measured using a FEMTO ${ }^{\circledR}$ spectrophotometer with a cuvette of $10-\mathrm{mm}$ path length. The detection limits (precision) of the measurements were $0.30 \mu \mathrm{M}(0.10 \mu \mathrm{M})$ for nitrate, $0.60 \mu \mathrm{M}(0.02 \mu \mathrm{M})$ for nitrite, $0.30 \mu \mathrm{M}(0.10 \mu \mathrm{M})$ for ammonium, $0.12 \mu \mathrm{M}(0.04 \mu \mathrm{M})$ for phosphate and $0.60 \mu \mathrm{M}(0.20 \mu \mathrm{M})$ for silicate.

\subsection{Microscopic analysis}

Phytoplankton were counted and identified from surface water samples and preserved in amber glass flasks ( $250 \mathrm{~mL})$ with $2 \%$ alkaline Lugol's iodine solution. $50 \mathrm{~mL}$-settling chambers were examined under an inverted microscope (Utermöhl, 1958; Sournia, 1978). Phytoplankton composition was determined using an Axiovert 135 ZEISS microscope, at $\times 200, \times 400$ and $\times 1000$ magnification, according to specific literature (mainly, Dodge, 1982; Hasle and Syvertsen, 1996). Cells were counted by enumerating at least 300 individuals of the most frequent species (Lund et al., 1958). Biovolume of phytoplankton cells $\left(\mu \mathrm{m}^{3}\right)$ was estimated based on the geometric shapes of each taxon, and then used to estimate the carbon biomass for each species/group $\left(\mu \mathrm{g} \mathrm{C} \mathrm{L}^{-1}\right)$ according to the literature (Putt and Stoecker, 1989; Verity et al., 1992; Montagnes et al., 1994; Menden-Deuer and Lessard, 2000). Identified species (or groups) were further classified as Flagellates I $(2-5 \mu \mathrm{m})$ including Phaeocystis antarctica during the spring cruise (when it was present in low numbers), and Flagellates II ( $>5 \mu \mathrm{m}$ ). The prymnesiophyte Phaeocystis antarctica was detected and counted separately in the summer cruise, when higher concentrations were observed. Coccolithophores, mainly represented by Emiliania huxleyi, comprised another individual group, as well as the silicoflagellate Dictyocha speculum. The class Cryptophyceae was not identified at species level. Among the dinoflagellates, some genera included several forms and were, for instance, 

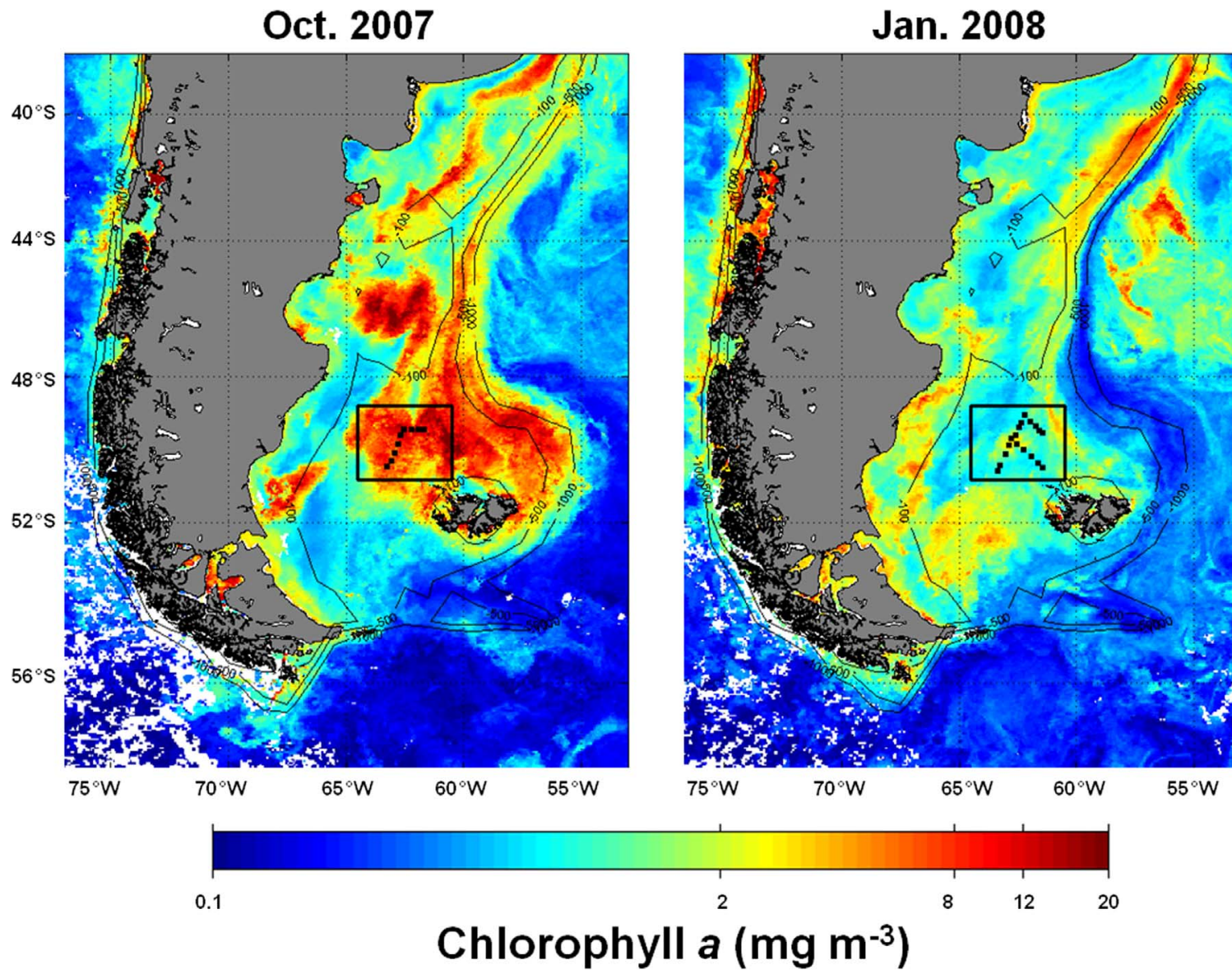

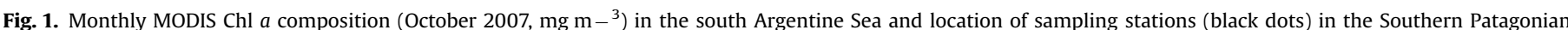

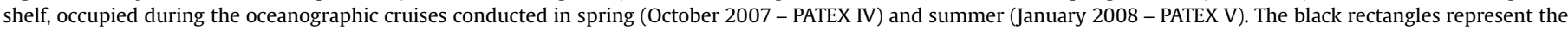
study area $\left(49-51^{\circ} \mathrm{S}\right.$ and $\left.61-64^{\circ} \mathrm{W}\right)$ used for retrieving synoptic averages of satellite time series analyses.

\section{Table 1}

Temperature and salinity intervals used to classify the water masses found in the region (Sub-Antarctic Shelf Water, and Sub-Antarctic Water) based on the values published for the region (Bianchi et al., 1982, 2005; Möller et al., 2008; Painter et al., 2010).

\begin{tabular}{|c|c|c|c|c|}
\hline \multirow[t]{2}{*}{ Water mass } & \multicolumn{2}{|l|}{ Spring } & \multicolumn{2}{|l|}{ Summer } \\
\hline & Temperature $\left({ }^{\circ} \mathrm{C}\right)$ & Salinity & Temperature $\left({ }^{\circ} \mathrm{C}\right)$ & Salinity \\
\hline $\begin{array}{l}\text { Sub-Antarctic } \\
\text { Shelf Water }\end{array}$ & $6.5-11.5$ & $33.3-34$ & 7-11.5 & $33.3-34$ \\
\hline $\begin{array}{l}\text { Sub-Antarctic } \\
\text { Water }\end{array}$ & $5-6.5$ & $33.4-34.2$ & $5-7$ & $33.4-34.2$ \\
\hline
\end{tabular}

represented as Cochlodinium sp., Gymnodinum spp., Gyrodinium sp. and Prorocentrum spp. (except Prorocentrum minimum, which was identified at species level). Other dinoflagellates were identified at order level (Peridiniales). When species identification of diatoms was not possible they were represented as Chaetoceros spp., Hemiaulus spp., Pseudo-nitzschia spp. and Thalassiosira spp. Other diatoms were identified at family level. Organisms belonging to the Euglenophyceae class were grouped at class level and ciliates were represented by the autotrophic Myrionecta rubra. Complementary information on summer assemblages is available in de Souza et al. (2012), where the phytoplankton organisms/groups were only presented in cell density.

\subsection{Pigment and CHEMTAX analyses}

Surface water samples for phytoplankton pigment analysis were collected in volumes ranging from 0.5 to $2 \mathrm{~L}$ (depending on the concentration of suspended material). These were immediately filtered (filtration not longer than $1 \mathrm{~h}$ ) onto Whatman $\mathrm{GF} / \mathrm{F}$ filters (nominal pore size $0.7-\mu \mathrm{m}$ and $25-\mathrm{mm}$ diameter) under vacuum pressure $<5 \mathrm{in}$. $\mathrm{Hg}$, and kept in liquid nitrogen until analysis. Photosynthetic pigments were extracted with $2 \mathrm{~mL}$ of $95 \%$ cold-buffered methanol ( $2 \%$ ammonium acetate) for $30 \mathrm{~min}$ at $-20^{\circ} \mathrm{C}$, in the dark. Samples were sonicated (Bransonic, model 1210) for $1 \mathrm{~min}$ at the beginning of the extraction period. The samples were centrifuged at $1100 \mathrm{~g}$ for $15 \mathrm{~min}$, at $4{ }^{\circ} \mathrm{C}$. Extracts were filtered (Fluoropore PTFE filter membranes, $0.2-\mu \mathrm{m}$ pore size) and immediately injected into the HPLC. Pigment extracts were analyzed using a Shimadzu HPLC that comprised a solvent delivery module ( $\mathrm{LC}-{ }_{10} \mathrm{ADVP}$ ) with system controller (SCL- ${ }_{10} \mathrm{AVP}$ ), a photodiode array (SPD-M $\left.\mathrm{M}_{10} \mathrm{ADVP}\right)$ and a fluorescence detector $\left(\mathrm{RF}-{ }_{10} \mathrm{AXL}\right)$. The chromatographic separation of pigments was achieved using a monomeric OS C8 column (Symmetry C8, 15-cm long, $4.6 \mathrm{~mm}$ in diameter and 3.5-mm particle size). Mobile phases were: (A) methanol:acetonitrile:aqueous pyridine solution (0.25 M, pH adjusted to 5.0 with acetic acid) (50:25:25, v/v/v); and (B) methanol:acetonitrile:acetone (20:60:20, v/v/v). The solvent gradient was generated with a flow rate of $1 \mathrm{~mL} \mathrm{~min}^{-1}$, an injection volume of $100 \mu \mathrm{L}$ and run duration of 40 min (Zapata et al., 2000; Mendes et al., 2007). Pigments were identified based on their absorbance spectra and retention times. Concentrations were calculated from the signals in the photodiode array detector or fluorescence detector (Ex. $430 \mathrm{~nm}$; Em. $670 \mathrm{~nm}$ ). Calibrations of the HPLC system were performed with pigment standards from Sigma (chlorophyll- $a$, chlorophyll- $b$ and $\beta$-carotene) and DHI (for 
other pigments). Chlorophyll $a$ (Chl a) concentration data from HPLC analysis were used as a phytoplankton biomass index, since this photosynthetic pigment is common to all autotrophic phytoplankton. In addition, the proportion of pheopigments a (Pheophytin $a+$ Pheophorbide $a / C h l a+$ Pheopigments $a$ ) was determined, since those pigments can be related to degradation of Chl $a$ due to grazing by zooplankton (Jeffrey et al., 1997; Mendes et al., 2012).

The relative abundance of phytoplankton contributing to total Chl $a$ biomass was calculated from pigment data using version 1.95 of CHEMTAX software (Mackey et al., 1996). CHEMTAX uses a factor analysis and steepest-descent algorithm to find the best fit to the data on to an initial pigment ratio matrix. The basis of calculations and procedures are fully described in Mackey et al. (1996). Based on microscopic observations and detected diagnostic pigments, the corresponding algal groups were loaded into CHEMTAX. All the methods regarding pigment/CHEMTAX analysis for the summer cruise are fully described in de Souza et al. (2012). Therefore, for the spring cruise, the algal groups were diatoms $\mathrm{A}$ [with Chlorophyll $c_{1}\left(\mathrm{Chl} c_{1}\right)$ ], diatoms B [with Chlorophyll $c_{3}$ (Chl $\left.c_{3}\right)$ ], Dinoflagellates-1 (Peridinin-containing dinoflagellates), Other flagellates [characterized by a pigment signature that includes $\mathrm{Chl}$ $c_{3}$, Chlorophyll $c_{2}$ (Chl $c_{2}$ ), 19'-butanoyloxyfucoxanthin (But-fuco), fucoxanthin (Fuco) and 19'-hexanoyloxyfuconxanthin (Hex-fuco), relative to a group including peridinin-lacking autotrophic dinoflagellates and other algal groups such as parmales and chrysophytes] and Green flagellates [with Chlorophyll $b(\mathrm{Chl} b)$ ]. The pigments loaded for the spring cruise were Chl $a$, Chl $b$, Chl $c_{1}$, Chl $c_{3}$, Peridinin (Perid), Fuco, But-fuco, Hex-fuco. Initial pigment:Chl $a$ input ratios were derived from the literature (Carreto et al., 2003; de Souza et al., 2012; Gonçalves-Araujo et al., 2012) (Table 2). For optimization of input matrices, a series of 60 pigment ratio tables was generated by multiplying each ratio of the initial table by a random function as described in Wright et al. (2009). The average of the best six output matrices for the spring cruise (with the lowest residual root mean square errors) were taken as the optimized results (Table 2). To make our results comparable between both cruises and for statistical analysis, all CHEMTAX-derived groups were arranged and classified in two datasets as follows: diatoms (sum of diatoms A and B), dinoflagellates, green flagellates (including prasinophytes), other flagellates (sum of the haptophytes E. huxleyi and P. antarctica, noticeably in the summer data set), cyanobacteria and cryptophytes (those latter two only present or detected in summer). These re-arrangements were adopted for showing the average contribution of those major phytoplankton groups in the study area. Moreover, given that the degradation products of Chl a (Pheophorbide $a$, Pheophytin $a$ and Chlorophyllide $a$ ) can be related to zooplankton grazing and/or senescence (Jeffrey et al., 1997; Mendes et al., 2012), we have obtained the relative concentration of degradation products (based on the average for all stations per cruise) in relation to the total Chl $a$ (Chl- $a+$ degradation products).

\subsection{Remote sensing data}

Satellite data on sea surface Chl $a$ concentration (SSC), calcite concentration (PIC), particulate organic carbon (POC) and sea surface temperature (SST) were retrieved from the Moderate Resolution Imaging Spectroradiometer on NASA's Aqua satellite (MODIS-Aqua) and presented as Level 3 (L3) SMI (Standard Mapped Image) 8-day composite images, at 9-km resolution. The surface chlorophyll $a$ [Chl $a$ ] concentration (SSC, in $\mathrm{mg} \mathrm{m}^{-3}$ ) was calculated using the OC3M empirical algorithm (Werdell and Bailey, 2005), which is derived from a relationship between in situ measurements of Chl $a$ concentration and blue-to-green band ratios of in situ remote sensing reflectance. Calcite, or particulate inorganic carbon concentration (PIC, in $\mathrm{mmol} \mathrm{m}^{-3}$ ), was calculated using observed in situ relationships between water-leaving radiances, spectral backscattering coefficients, and concentrations of PIC (i.e., calcium carbonate or calcite), using a 2-band approach (Balch et al., 2005). When that failed, the PIC algorithm was calculated using a 3-band approach (Gordon et al., 2001). The concentration of particulate organic carbon ( $\mathrm{POC}$, in $\mathrm{mg} \mathrm{m}^{-3}$ ) was estimated by an empirical relationship (Stramski et al., 2008) derived from in situ measurements of POC and blue-to-green band ratios of remote sensing reflectance. Both the OC3M Chl $a$ and PIC algorithms have been shown to present good estimates in Argentinean continental shelf waters (Garcia et al., 2011; Ferreira et al., 2013). Time-series data of SSC, PIC, POC and SST were extracted based on the synoptic mean of each variable in the area located within $49-51^{\circ} \mathrm{S}$ and $61-64^{\circ} \mathrm{W}$ (see squares in Fig. 1). The satellite data comprised the period from 1 August 2007 to 31 January 2008, which included both study seasons and were used as complementary information to the in situ sampling regarding the temporal setting of our sampling campaigns.

\subsection{Statistical analyses}

Relationships among all pairs of variables were investigated using Spearman-r correlation coefficients. In order to compare variables between both sampling periods, Kruskal-Wallis $\mathrm{H}$ tests were applied using the software MathWorks MATLAB ${ }^{\circledR}$. Canonical correspondence analysis (CCA) was performed with the software CANOCO to evaluate main patterns of phytoplankton community variability, as influenced by environmental variation, and main patterns in the weighted means of each species (or group) due to environmental variables (ter Braak and Prentice, 1988). For this analysis, data from all occupied stations in both cruises were considered, except one station (January 2008) in which no CTD data were collected, totaling a set of 26 cases. The biotic matrix

Table 2

Input and output ratios of marker pigments to $\mathrm{Chl} a$ in the spring cruise.

\begin{tabular}{|c|c|c|c|c|c|c|c|c|}
\hline Class/Pigment & Chl $c_{1}$ & Chl $c_{2}$ & Perid & Fuco & But-fuco & Hex-fuco & Chl b & Chl a \\
\hline \multicolumn{9}{|l|}{ Input matrix } \\
\hline Diatoms A & 0.178 & 0 & 0 & 0.863 & 0 & 0 & 0 & 1 \\
\hline Diatoms B & 0 & 0.033 & 0 & 0.610 & 0 & 0 & 0 & 1 \\
\hline Dinoflagellates-1 & 0 & 0 & 0.800 & 0 & 0 & 0 & 0 & 1 \\
\hline Other flagellates & 0 & 0.243 & 0 & 0.313 & 0.280 & 0.491 & 0 & 1 \\
\hline Green flagellates & 0 & 0 & 0 & 0 & 0 & 0 & 0.693 & 1 \\
\hline \multicolumn{9}{|l|}{ Output matrix } \\
\hline Diatoms A & 0.099 & 0 & 0 & 0.959 & 0 & 0 & 0 & 1 \\
\hline Diatoms B & 0 & 0.130 & 0 & 1162 & 0 & 0 & 0 & 1 \\
\hline Dinoflagellates-1 & 0 & 0 & 0.695 & 0 & 0 & 0 & 0 & 1 \\
\hline Other flagellates & 0 & 0.023 & 0 & 0.167 & 0.232 & 0.337 & 0 & 1 \\
\hline Green flagellates & 0 & 0 & 0 & 0 & 0 & 0 & 0.389 & 1 \\
\hline
\end{tabular}


was composed by biomass of the main phytoplankton taxonomic groups determined from HPLC/CHEMTAX analysis, taking into account strong associations with the microscopic data (see de Souza et al. (2012), for further details). The environmental matrix included the following variables: surface temperature, salinity, DIN, phosphate, silicate, UMLD and stability. All variables were log-transformed prior to analysis to reduce the influence of the different scales in the sets of variables. In order to test for significance of the CCA, Monte-Carlo tests were run based on 499 permutations under reduced model $(p<0.05)$. The two first significant canonical roots were used to produce the canonical diagram. The canonical roots are the weighted sums of the phytoplankton variables, which are used to calculate the position of the stations in the diagram, according to their phytoplankton species (or groups) composition and abundance. Thus, the distances between stations in the ordination diagram reflect the similarity of their phytoplankton assemblages (ter Braak, 1994). Canonical factor loadings are simple correlations between the environmental variables and the canonical roots, and are considered a measure of the importance of the different environmental variables determining phytoplankton variability within the area. Since a great abundance of diatoms in spring was clearly determined by both microscopic counts and pigment analysis, no correlation analysis between these approaches was applied, as it has been done for the summer data set (de Souza et al., 2012).

\section{Results}

\subsection{Environmental setting}

Vertical density profiles showed noticeable differences in the water column structure between the sampling periods (Fig. 2). Mean surface temperature was significantly $(\mathrm{p}<0.01)$ lower $\left(7.25 \pm 0.43^{\circ} \mathrm{C}\right)$ in spring as compared to summer $\left(11.03 \pm 0.23^{\circ} \mathrm{C}\right.$ ) (Fig. 2, Table 3). Salinity did not vary between the sampling periods ( $\mathrm{p}>0.05$ ), oscillating around 33.53. Deeper UMLD $(57 \pm 7 \mathrm{~m})$ and relatively low stability $\left(236 \times 10^{-8} \pm 73 \times 10^{-8} \mathrm{rad}^{2} \mathrm{~m}^{-1}\right)$ were found during the springtime, whereas shallow UMLD $(35 \pm 3 \mathrm{~m})$ and well-stratified water column $\left(772 \times 10^{-8} \pm 161 \times 10^{-8} \mathrm{rad}^{2} \mathrm{~m}^{-1}\right)$ were noticeable for the summer period (Table 3).

Regarding the surface distribution of dissolved inorganic macronutrients, both DIN and silicate concentrations were significantly
Table 3

Average and ranges of some variables at surface, during spring and summer cruises: Temperature $\left({ }^{\circ} \mathrm{C}\right)$, Salinity, UMLD $(\mathrm{m})$, Stability $\left(10^{-8} \mathrm{rad}^{2} \mathrm{~m}^{-1}\right)$, Dissolved Inorganic Nitrogen (DIN, $\mu \mathrm{M})$, Phosphate $(\mu \mathrm{M})$, Silicate $(\mu \mathrm{M}), \mathrm{N}: \mathrm{P}$ ratio, N:Si ratio and Chl $a\left(\mathrm{mg} \mathrm{m}^{-3}\right)$. $p$-Values indicate the significance level of the difference between spring and summer cruises based on Kruskal-Wallis $H$-test. $(p>0.05=$ not significant).

\begin{tabular}{llllll}
\hline & \multicolumn{2}{l}{ Spring } & \multicolumn{2}{l}{ Summer } & $\boldsymbol{p}$-Value \\
\hline Temperature ( & & & \\
Salinity & 7.25 & $(6.76-7.96)$ & 11.03 & $(10.47-11.36)$ & $<0.01$ \\
UMLD (m) & 33.53 & $(33.40-33.63)$ & 33.53 & $(33.36-33.60)$ & $>0.05$ \\
Stability & 57 & $(47-67)$ & 35 & $(30-38)$ & $<0.01$ \\
$\quad\left(\mathbf{1 0}^{-\mathbf{8}}\right.$ rad $\left.^{\mathbf{2}} \mathbf{~ m}^{-\mathbf{1}}\right)$ & 236 & $(140-362)$ & 772 & $(461-964)$ & $<0.01$ \\
DIN $(\boldsymbol{\mu M})$ & 1.83 & $(0.52-4.41)$ & 3.06 & $(0.73-4.77)$ & $<0.05$ \\
Phosphate $(\boldsymbol{\mu M})$ & 0.11 & $(0.03-0.23)$ & 0.16 & $(0.00-0.33)$ & $>0.05$ \\
Silicate $(\boldsymbol{\mu} \mathbf{M})$ & 0.22 & $(0.09-0.37)$ & 0.62 & $(0.19-1.35)$ & $<0.05$ \\
$\mathbf{N}: \mathbf{P}$ & 23.31 & $(7.42-50.67)$ & 18.01 & $(5.35-39.82)$ & $>0.05$ \\
$\mathbf{N}: S i$ & 12.35 & $(2.06-49.00)$ & 6.81 & $(0.54-23.05)$ & $>0.05$ \\
Chl $\boldsymbol{a}\left(\mathbf{m g ~ m}^{-\mathbf{3}}\right)$ & 8.68 & $(2.98-16.26)$ & 0.56 & $(0.29-1.48)$ & $<0.01$ \\
\hline
\end{tabular}

$(\mathrm{p}<0.05)$ higher in summer $(3.06 \mu \mathrm{M}$ of DIN and $0.62 \mu \mathrm{M}$ of silicate) than in spring $(1.83 \mu \mathrm{M}$ of DIN and $0.22 \mu \mathrm{M}$ of silicate), on average (Table 3). However, there was no significant difference between phosphate concentrations (on average, $0.16 \mu \mathrm{M}$ in summer and $0.11 \mu \mathrm{M}$ in spring; $\mathrm{p}>0.05$ ) (Table 3 ). The ratios between dissolved inorganic nutrients ( $\mathrm{N}: \mathrm{P}$ and $\mathrm{N}: \mathrm{Si}$ ) were highly variable over the study area in both seasons and, therefore, mean values showed no significant differences between the cruises (Table 3). N:P values in spring (23.31) were slightly higher than in summer (18.01), with similar situation was observed for $\mathrm{N}: \mathrm{Si}$, with average values of 12.35 and 6.81 for spring and summer, respectively.

Regarding water masses distribution, although analysis of volumetric changes of water masses were not performed, a great influence of the Sub-Antarctic Water was observed, commonly found below $50 \mathrm{~m}$ in summertime. On the other hand, in summer, a massive presence of the Sub-Antarctic Shelf Water (SASW) was strikingly seen at upper layers (Fig. 2). Moreover, a slight spatial gradient in salinity was observed in both sampling periods, with higher values always in the northeastern sector of the study area. Salinity was positively (negatively) correlated $(p<0.01)$ with longitude (latitude), highlighting the lowest salinity at the southwestern part of the study area (not shown).
SUMMER SPRING

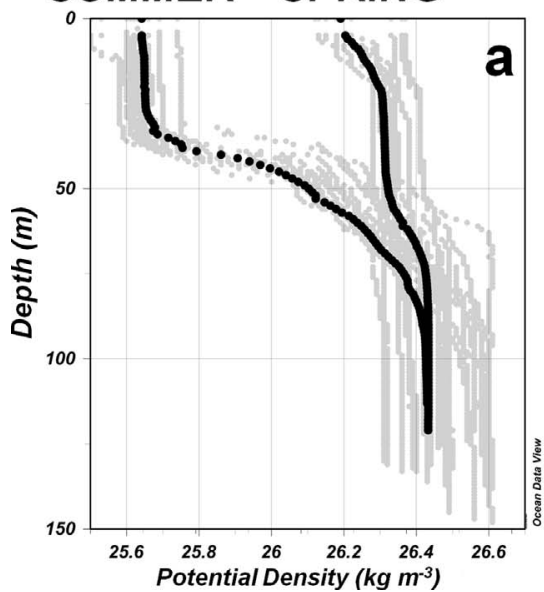

SPRING

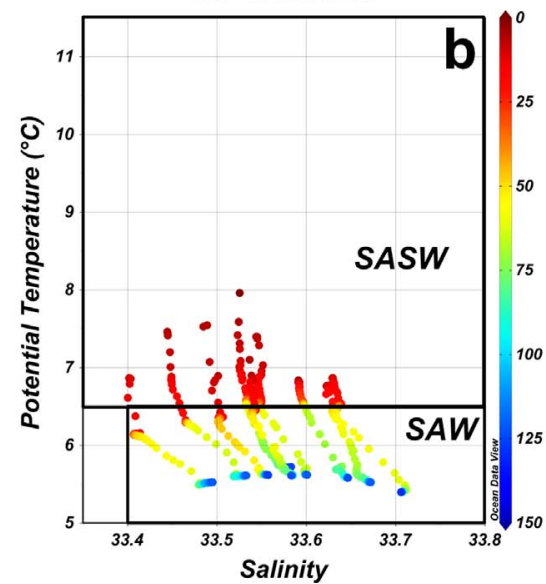

SUMMER

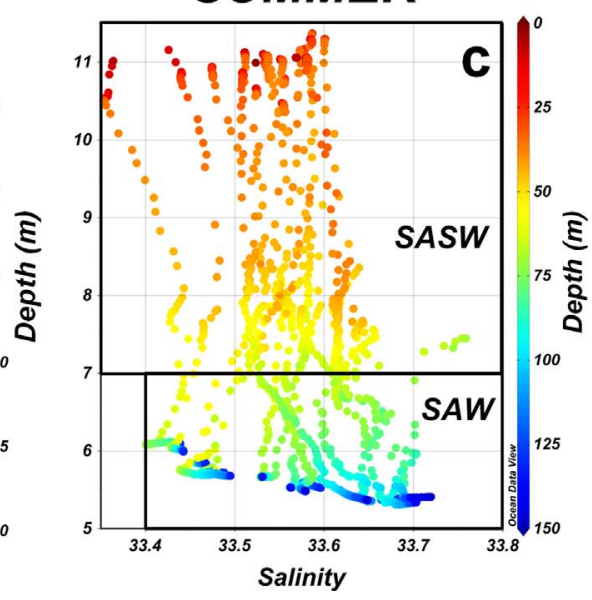

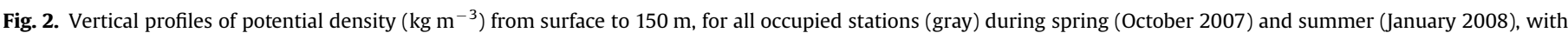

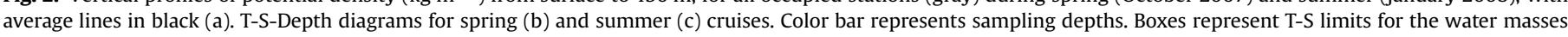

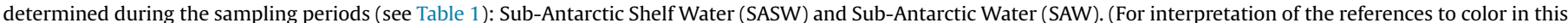
figure legend, the reader is referred to the web version of this article.) 


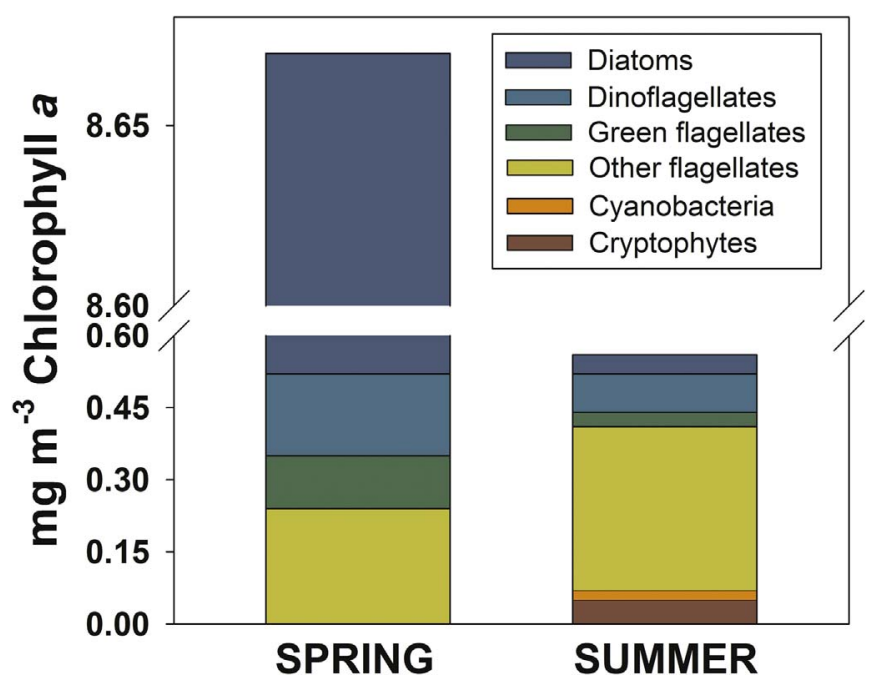

Fig. 3. Seasonal average of absolute contribution ( $\mathrm{mg} \mathrm{m}^{-3}$ of Chl $a$ ) of major phytoplankton groups derived from HPLC/CHEMTAX analysis in both sampling periods. For more details on the summer data set, see de Souza et al. (2012).

\subsection{Pigments and phytoplankton community structure}

Phytoplankton biomass, expressed as Chl $a$, attained much higher values in spring (ranging from 2.98 to $16.3 \mathrm{mg} \mathrm{m}^{-3}$, mean $8.68 \mathrm{mg} \mathrm{m}^{-3}$ ) than in summer (from 0.29 to $1.48 \mathrm{mg} \mathrm{m}^{-3}$, mean $0.56 \mathrm{mg} \mathrm{m}^{-3}$ ) (Fig. 3 and Table 3 ). Such contrasting values were also found among accessory pigments, where a dominance of Fuco was observed during the spring cruise while significantly lower values were registered during the summer cruise (Table 4). In summer, other pigments were also important, such as Hex-fuco and Perid (the latter was higher in spring, but represented a 1 ower proportion of the total pigment pool in that period). Three types of Chl $a$ degradation products were identified and quantified: chlorophyllide- $a$ (Chlide $a$ ), pheophytin- $a$ (Phytin $a$ ) and

\section{Table 4}

Concentrations (seasonal average and range) and relative contribution of pigments detected in this study, including those from the summer data set [see de Souza et al. (2012)].

\begin{tabular}{|c|c|c|c|c|}
\hline \multirow[t]{2}{*}{ Pigments } & \multicolumn{2}{|l|}{ Spring } & \multicolumn{2}{|l|}{ Summer } \\
\hline & $\mathrm{mg} \mathrm{m}^{-3}$ & $\%$ & $\mathrm{mg} \mathrm{m}^{-3}$ & $\%$ \\
\hline Chlorophyll a & $8.68(2.98-16.26)$ & 78 & $0.56(0.29-1.48)$ & 69 \\
\hline Chlorophyll b & $0.09(0.03-0.21)$ & 1 & $0.03(0.00-0.08)$ & 3 \\
\hline Chlorophyll $c_{1}$ & $0.85(0.16-1.81)$ & 8 & 0 & 0 \\
\hline Chlorophyll $c_{2}$ & $1.25(0.40-2.55)$ & 11 & $0.11(0.04-0.36)$ & 14 \\
\hline Chlorophyll $c_{3}$ & $0.29(0.01-0.65)$ & 2 & $0.11(0.00-0.37)$ & 14 \\
\hline Total Chlorophylls & 11.16 & 100 & 0.81 & 100 \\
\hline Fucoxanthin & $6.30(2.44-11.76)$ & 84 & $0.15(0.03-0.96)$ & 16 \\
\hline Peridinin & $0.25(0.12-0.41)$ & 3 & $0.16(0.00-0.44)$ & 17 \\
\hline Diadinoxanthin & $0.61(0.29-1.15)$ & 8 & $0.15(0.06-0.33)$ & 16 \\
\hline 19 '-hexanoyloxyfucoxanthin & $0.10(0.06-0.20)$ & 1 & $0.32(0.08-0.69)$ & 34 \\
\hline $19^{\prime}$-butanoyloxyfucoxanthin & $0.05(0.00-0.10)$ & 1 & $0.06(0.02-0.10)$ & 6 \\
\hline Alloxanthin & 0 & 0 & $0.03(0.00-0.12)$ & 3 \\
\hline Prasinoxanthin & 0 & 0 & $0.01(0.00-0.03)$ & 1 \\
\hline Diatoxanthin & $0.25(0.07-0.72)$ & 3 & $0.02(0.00-0.07)$ & 2 \\
\hline Zeaxanthin & 0 & 0 & $0.03(0.00-0.06)$ & 3 \\
\hline Total carotenoids & 7.56 & 100 & 0.93 & 100 \\
\hline Pheophorbide $a$ & $0.42(0.13-0.89)$ & 32 & $0.01(0.00-0.02)$ & 33 \\
\hline Pheophytin a & $0.57(0.21-1.08)$ & 44 & $0.02(0.00-0.04)$ & 67 \\
\hline Chlorophyllide $a$ & $0.32(0.00-0.81)$ & 24 & 0 & 0 \\
\hline Total degradation products & 1.31 & 100 & 0.03 & 100 \\
\hline
\end{tabular}

pheophorbide- $a$ (Phide $a$ ), with concentrations significantly higher in spring $(\mathrm{p}<0.05)$ than in summer. Chlide $a$ varied from 0 to $0.81 \mathrm{mg} \mathrm{m}^{-3}$ in spring, but it was undetectable in summer. Phide $a$ ranged from 0.13 to $0.89 \mathrm{mg} \mathrm{m}^{-3}$ in spring, but presented a much lower range $\left(0-0.02 \mathrm{mg} \mathrm{m}^{-3}\right)$ in summer. Phytin $a$ also showed higher concentrations $\left(0.21-1.08 \mathrm{mg} \mathrm{m}^{-3}\right)$ in spring than in summer (0-0.04 $\mathrm{mg} \mathrm{m}^{-3}$ ) (see Table 4). In relative terms, degradation products (Phytin and Phide $a$ ) were a greater percentage of total (Chl $a+$ pheopigments) in spring ( $\sim 14 \%)$ than in summer ( $\sim 5 \%)$.

The differences found in absolute and relative pigment concentrations reflected the differences observed in the structure of the phytoplankton communities, as seen in the relative composition of CHEMTAX-based groups at both seasons (see Fig. 3). Diatoms massively dominated in springtime (reaching $>81 \%$ of total Chl $a$ ), with a homogeneous spatial distribution of phytoplankton (not shown). Those organisms were accompanied by smaller percentages of small flagellates (green flagellates and other flagellates) and peridinin-containing dinoflagellates. By contrast, in summer, greater spatial variability was observed (see de Souza et al. (2012)) when the 'other flagellates' group (sum of Emiliania huxleyi and Phaeocystis antarctica) and dinoflagellates were predominant (Fig. 3).

In terms of average carbon biomass (Table 5), the main spring diatoms were represented by the large cell-sized Corethron pennatum (153.60 $\left.\mu \mathrm{g} \mathrm{C} \mathrm{L}^{-1}\right)$, small cells of Thalassiosira spp. ( $<20 \mu \mathrm{m}$; $\left.64.41 \mu \mathrm{g} \mathrm{C} \mathrm{L}^{-1}\right)$, pennates Naviculaceae $\left(3.61 \mu \mathrm{g} \mathrm{C} \mathrm{L}^{-1}\right)$, Pseudonitzschia spp. $\left(2.36 \mu \mathrm{g} \mathrm{C} \mathrm{L}^{-1}\right)$ and Thalassiothrix antarctica $\left(1.17 \mu \mathrm{g} \mathrm{C} \mathrm{L}^{-1}\right)$. On the other hand, Cylindrotheca closterium (6.53 $\mu \mathrm{g} \mathrm{C} \mathrm{L}^{-1}$ ) was a major contributor to phytoplankton carbon biomass in the subsequent summer. Nano-dinoflagellates Prorocentrum minimum $\left(1.54 \mu \mathrm{g} \mathrm{C} \mathrm{L}^{-1}\right)$, Gymnodinium spp. (3.32 $\left.\mu \mathrm{g} \mathrm{C} \mathrm{L}^{-1}\right)$ and peridiniales $\left(6.16 \mu \mathrm{g} \mathrm{C} \mathrm{L}^{-1}\right)$ were mostly prominent in spring and those were replaced by larger species such as Dinophysis okamurai $\left(1.33 \mu \mathrm{g} \mathrm{C} \mathrm{L}^{-1}\right)$, Scrippsiella trochoidea (3.26 $\mu \mathrm{g} \mathrm{C} \mathrm{L}^{-1}$ ) and the complex Ceratium lineatum-C. pentagonum (5.83 $\mu \mathrm{g} \mathrm{C} \mathrm{L}{ }^{1}$ ) in summer. However, the summer assemblage was mostly characterized by large contributions of coccolithophores (20.61 $\left.\mu \mathrm{g} \mathrm{C} \mathrm{L}^{-1}\right)$ and Phaeocystis antarctica $\left(7.78 \mu \mathrm{g} \mathrm{C} \mathrm{L}^{-1}\right)$. There was also a noteworthy higher contribution of the autotrophic ciliate Myrionecta rubra in summer $\left(5.40 \mu \mathrm{g} \mathrm{C} \mathrm{L}^{-1}\right)$ than in spring $\left(0.76 \mu \mathrm{g} \mathrm{C} \mathrm{L}^{-1}\right)$. Other flagellates such as cryptophytes $\left(0.19 \mu \mathrm{g} \mathrm{C} \mathrm{L}^{-1}\right.$ and $0.01 \mu \mathrm{g} \mathrm{C} \mathrm{L}^{-1}$ in summer and spring, respectively), euglenophytes $\left(0.09 \mu \mathrm{g} \mathrm{C} \mathrm{L}^{-1}\right)$ and the silicoflagellate Dictyocha speculum $\left(0.02 \mu \mathrm{g} \mathrm{C} \mathrm{L}{ }^{-1}\right)$ (those latter two only found in spring) did not contribute substantially to autotrophic carbon biomass (Table 5).

\subsection{Relationship between seasonal phytoplankton communities and oceanographic conditions}

A Monte Carlo permutation test of F-ratio, applied to the CCA analysis (Fig. 4), showed that the environmental variables (temperature, salinity, DIN, phosphate, silicate, UMLD and stability) reasonably explained $(83.0 \%)$ thepartially seasonal distribution of phytoplankton groups $(\mathrm{p}<0.01)$. The first two significant canonical roots cumulatively explained $97.2 \%$ of the observed variance in phytoplankton composition. The first canonical root, explaining almost all the phytoplankton variation (87.6\%), clearly distinguished diatoms associated with deeper UMLD from other phytoplankton groups (cyanobacteria, cryptophytes, other flagellates, green flagellates and dinoflagellates) most positively related to temperature, stability and nutrients.

A strong association between the phytoplankton community and water column structure was also evident by high factor loadings of temperature, stability and UMLD in the first canonical 
Table 5

Mean (minimum and maximum) surface phytoplankton biomass ( $\mu \mathrm{g} \mathrm{C} \mathrm{L}^{-1}$ ) for spring and summer, based on microscopic analysis.

\begin{tabular}{|c|c|c|c|c|}
\hline \multirow[t]{2}{*}{ Taxonomic groups } & \multicolumn{2}{|l|}{ Spring } & \multicolumn{2}{|c|}{ Summer } \\
\hline & Mean & $\begin{array}{l}\text { (Min- } \\
\text { Max) }\end{array}$ & Mean & $\begin{array}{l}\text { (Min- } \\
\text { Max) }\end{array}$ \\
\hline $\begin{array}{l}\text { Flagellates I }(2-5 \mu \mathrm{m} \text {; including } \\
\text { Phaeocystis antarctica })\end{array}$ & 2.4 & $(1.5-4.4)$ & 1.65 & $(0.5-3.1)$ \\
\hline Flagellates II $(>5 \mu \mathrm{m})$ & 0.8 & $(0.5-1.6)$ & 0.24 & $(0-1.0)$ \\
\hline Phaeocystis antarctica & & & 7.78 & $(1.4-20.3)$ \\
\hline $\begin{array}{l}\text { Coccolithophorids (mainly Emiliania } \\
\text { huxleyi) }\end{array}$ & & & 20.61 & $(0.6-82.0)$ \\
\hline Dictyocha speculum & 0.02 & $(0-0.1)$ & & \\
\hline Class Cryptophyceae & 0.01 & $(0-0.1)$ & 0.19 & $(0-1.0)$ \\
\hline \multicolumn{5}{|l|}{ Class Dinophyceae } \\
\hline Ceratium fusus & & & 0.18 & $(0-0.7)$ \\
\hline Ceratium lineatum $+C$. pentagonum & 0.05 & $(0-0.2)$ & 5.83 & $(0.2-13.6)$ \\
\hline Cochlodinium sp. & 0.88 & $(0-2.0)$ & 0.05 & $(0-0.3)$ \\
\hline Dinophysis okamurai & & & 1.33 & $(0-3.8)$ \\
\hline Gonyaulax scrippsae & & & 0.16 & $(0-1.4)$ \\
\hline Gymnodinium spp. I ( $<20 \mu \mathrm{m})$ & 3.32 & $(0.8-7.4)$ & 1.55 & $(0-5.4)$ \\
\hline Gymnodinium spp. II ( $>20 \mu \mathrm{m})$ & 1.25 & $(0.1-2.4)$ & 0.32 & $(0-0.9)$ \\
\hline Gyrodinium sp. $(10 \mu \mathrm{m})$ & & & 0.16 & $(0-0.8)$ \\
\hline Oxytoxum variabile & 0.66 & $(0-3.0)$ & 0.01 & $(0-0.02)$ \\
\hline Peridiniales I $(<20 \mu \mathrm{m})$ & 6.16 & $(2.4-16.7)$ & 0.31 & $(0-1.9)$ \\
\hline Peridiniales II ( $>20 \mu \mathrm{m})$ & 0.21 & $(0.1-0.5)$ & 0.03 & $(0-0.5)$ \\
\hline Prorocentrum minimum & 1.54 & $(0-3.9)$ & 1.56 & $(0-24.1)$ \\
\hline Prorocentrum spp. ( > $20 \mu \mathrm{m})$ & 0.03 & $(0-0.1)$ & 0.56 & $(0-5.0)$ \\
\hline Scrippsiella trochoidea & 0.03 & $(0-0.2)$ & 3.26 & $(0-19.8)$ \\
\hline Torodinium robustum & 0.15 & $(0-0.6)$ & 0.31 & $(0-0.9)$ \\
\hline \multicolumn{5}{|l|}{ Class Bacillariophyceae } \\
\hline Chaetoceros spp. I $(<10 \mu \mathrm{m})$ & 0.88 & $(0-3.5)$ & & \\
\hline Chaetoceros spp. II ( > $10 \mu \mathrm{m})$ & 0.17 & $(0.1-0.7)$ & & \\
\hline Corethron pennatum & 153.6 & $(0-577.0)$ & & \\
\hline Cylindrotheca closterium & & & 6.53 & $(0-100.7)$ \\
\hline Eucampia antarctica & 0.32 & $(0-1.1)$ & & \\
\hline Guinardia tubiformis & 0.03 & $(0-0.1)$ & & \\
\hline Hemiaulus spp. & 0.29 & $(0-1.9)$ & & \\
\hline Naviculaceae I (40 $\mu \mathrm{m}$ in length) & 0.14 & $(0.1-0.4)$ & & \\
\hline Naviculaceae II (60-80 $\mu \mathrm{m}$ in length) & 3.47 & $(1.2-8.5)$ & & \\
\hline Pseudo-nitzschia spp. & 2.36 & $(0.5-7.1)$ & & \\
\hline Thalassionema nitzschioides & 0.03 & $(0-0.3)$ & & \\
\hline Thalassiosira spp. I ( $<20 \mu \mathrm{m})$ & 64.41 & $(31.2-136.3)$ & & \\
\hline Thalassiosira spp. II $(>20-50 \mu \mathrm{m})$ & 0.82 & $(0-2.3)$ & & \\
\hline Thalassiosira sp. III ( > 50-100 $\mu \mathrm{m})$ & 0.06 & $(0-0.5)$ & & \\
\hline Thalassiothrix antarctica & 1.17 & $(0-3.3)$ & & \\
\hline Class Euglenophyceae & 0.09 & $(0-0.5)$ & & \\
\hline \multicolumn{5}{|l|}{ Ciliophora } \\
\hline Myrionecta rubra $(10-15 \mu \mathrm{m})$ & 0.27 & $(0-1.5)$ & & \\
\hline M. rubra $(30 \mu \mathrm{m})$ & 0.76 & $(0-1.6)$ & 5.40 & $(0-34.2)$ \\
\hline
\end{tabular}

root (see Fig. 4). Overall, the first canonical root seemed to indicate a seasonal change both in the water column structure and, consequently, in the phytoplankton community. Thus, the spring period was linked to deeper UMLD and prevalence of diatoms, while the summer period was linked to the remaining environmental variables and all other phytoplankton groups (Fig. 4).

The time-series analysis of remote sensing data (weekly synoptic averages) showed a clear seasonal variability in SSC, SST, calcite and POC over the analyzed period (Fig. 5). Average SST in late austral winter/early spring was $>6{ }^{\circ} \mathrm{C}$, increasing with season progression up to a maximum of $14^{\circ} \mathrm{C}$ in summer, with a peak in March 2008. SSC average, as expected, showed the greatest peak (about $12.3 \mathrm{mg} \mathrm{m}^{-3}$ ) in spring (October 2007), with mean surface values lower than $3 \mathrm{mg} \mathrm{m}^{-3}$ during the summer season (see Fig. 5). POC was correlated to SSC (SSC $=0.023^{*} \mathrm{POC}-2.691$; $\left.\mathrm{r}^{2}=0.95 ; \mathrm{p}<0.001\right)$, reaching up to $490 \mathrm{mg} \mathrm{m}^{-3}$ during the spring

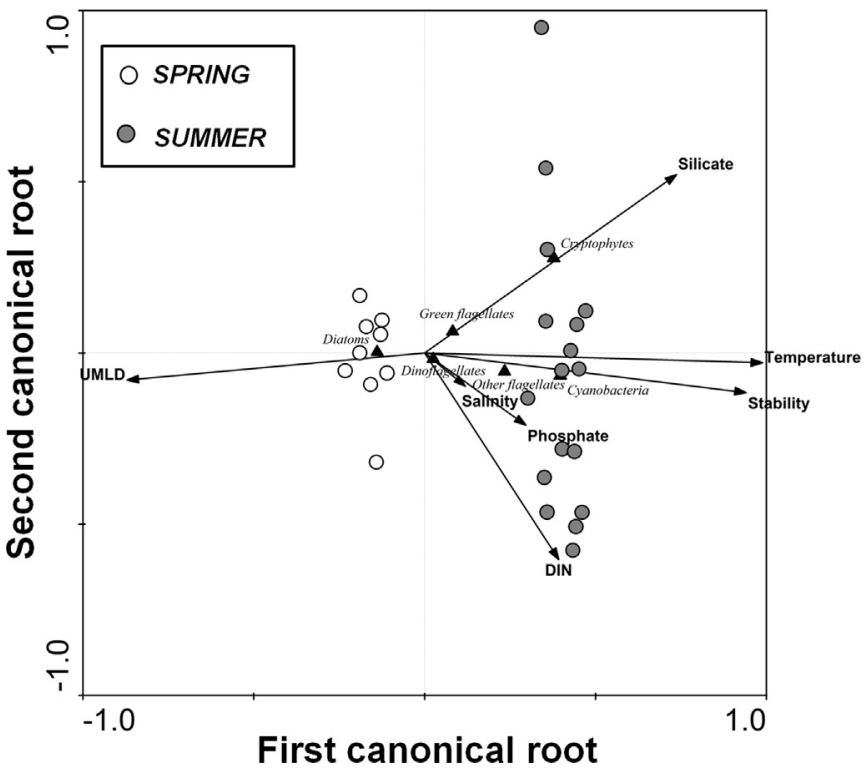

Fig. 4. Canonical correspondence analysis ordination diagram based on surface phytoplankton community data (from HPLC/CHEMTAX analysis) with $83.0 \%$ of explanation (the first two canonical roots explained together 97.2\%) of the phytoplankton groups-environmental relationships. Circles represent all sampling stations occupied both in October 2007 (white) and in January 2008 (gray). Arrows denote the environmental variables. Phytoplankton groups are symbolized by triangles.

peak and averages were close to $300 \mathrm{mg} \mathrm{m}^{-3}$ during the summer period (see Fig. 5). Averaged calcite concentration was low during spring $\left(<1 \mathrm{mmol} \mathrm{m}^{-3}\right.$ ) with a peak in December (reaching up to $4 \mathrm{mmol} \mathrm{m} \mathrm{m}^{-3}$ ). Based on the time-series, the spring cruise was shown to be carried out a few weeks after the peak of the phytoplankton bloom (determined by both Chl $a$ and POC fluctuations), while the summer cruise was conducted within the calcite peak period, associated with a moderate increase in phytoplankton biomass, in December 2007/January 2008 (Fig. 5).

\section{Discussion}

\subsection{Environmental features in the southern Patagonian mid shelf}

This work provides original results on phytoplankton biomass and composition from a particular area of the southern Patagonian shelf (49-51 ${ }^{\circ} \mathrm{S}$ and $\left.61-64^{\circ} \mathrm{W}\right)$, which has been shown to be highly productive (El-Sayed, 1967; Dogliotti et al., 2014), during two sequential seasons (spring 2007 and summer 2008) of pronounced autotrophic growth. In general, the upper mixed layer was characterized by the presence of SASW in both campaigns, and it has been shown to be the dominant surface water mass along the midand outer Patagonian shelf region (Bianchi et al., 1982, 2005). A subtle, latitudinal salinity gradient was observed in spring, with lower salinity waters in the southwestern sector of the study area, as was also pointed out for summer in de Souza et al. (2012). However, there was no significant difference in average salinities between the spring and summer cruises. Similar thermohaline ranges and distributional pattern of water masses have been previously shown across the southern Patagonian shelf (Sabatini et al., 2004; Bianchi et al., 2005; Painter et al., 2010). In the present study, the SAW was detected at all stations as the dominant water mass signal underneath the upper mixed layer, as previously reported in the region (Bianchi et al., 1982, 2005; Painter et al., 2010). Furthermore, certain variability in the layer thickness occupied by each of the water masses was observed (see Fig. 2): the 


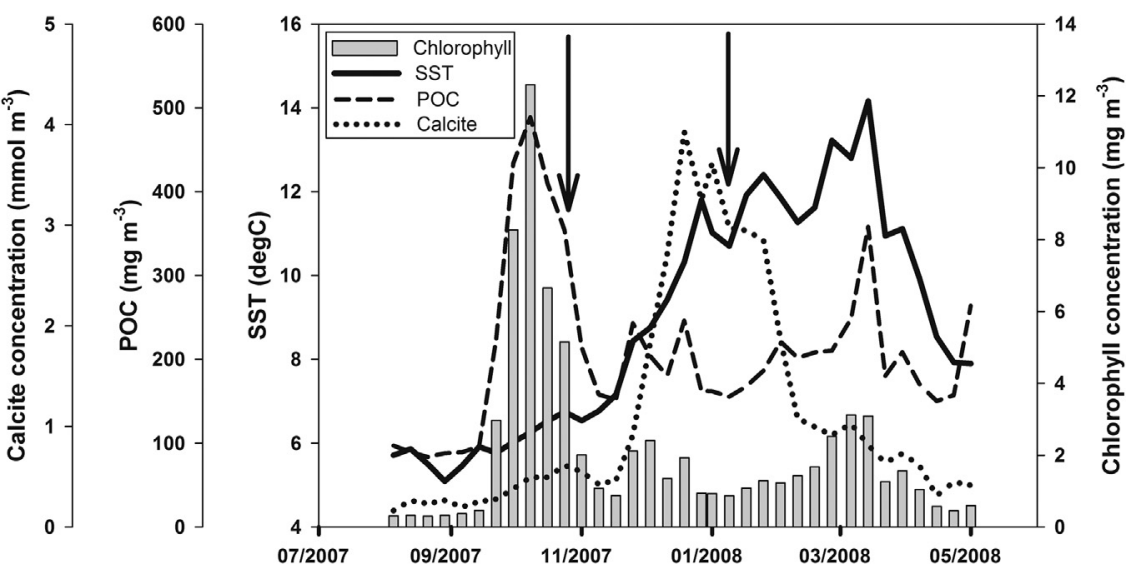

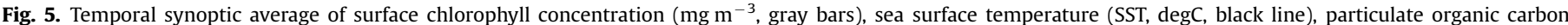

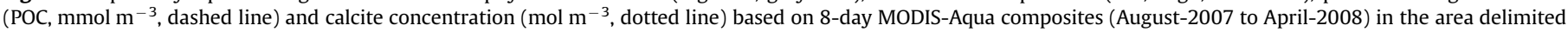
by $49-51^{\circ} \mathrm{S}$ and $61-64^{\circ} \mathrm{W}$ (see Fig. 1). Arrows indicate the approximate time intervals of the spring (21-22 October 2007) and summer (04-07 January 2008$)$ cruises.

SASW was detected in a thicker layer in summer than in spring and, the reverse was observed for the SAW. This variability seems to be related to the seasonal heating (of $\sim 4{ }^{\circ} \mathrm{C}$ ) observed in the surface layer (see Fig. 2), with potential implications on volumetric changes (Möller et al., 2008); however, volumetric information was not within the goals of this work and it can be more thoroughly explored in further studies. The thermohaline structure was strikingly different between spring (average UMLD of $57 \mathrm{~m}$ and weak stratification) and summer (average UMLD of $35 \mathrm{~m}$ and well stratified water column), as previously suggested in studies conducted in the region (e.g. Bianchi et al., 2005).

Water column stability has been pointed out as a classically important feature in triggering phytoplankton spring blooms in the Patagonian shelf-break, where mean stability indices varying from 220 to $740 \times 10^{-8} \mathrm{rad}^{2} \mathrm{~m}^{-1}$ were inversely related with Chl $a$ levels (Garcia et al., 2008). In the present work, stability levels were within a similar range of $236 \times 10^{-8} \pm 73 \times 10^{-8}$ rad $^{2} \mathrm{~m}^{-1}$ during spring (associated with higher $\mathrm{Chl} a$ ), but showing much higher values in summer $\left(772 \times 10^{-8} \pm 161 \times 10^{-8} \mathrm{rad}^{2} \mathrm{~m}^{-1}\right.$; with lower Chl a). Stronger water column stratification in summer as compared to spring in the southern Patagonian shelf was also reported for the austral spring/summer season of 2005/2006 (Dogliotti et al., 2014).

The range of nutrient concentrations observed in this study agrees with previous reports for the region (Paparazzo et al., 2010; Paparazzo, 2011; Balch et al., 2014; Valiadi et al., 2014). Even considering our relatively restricted study area, a subtle spatial variation in DIN distribution was observed at surface during the spring season. Higher concentrations of DIN $(>1.5 \mu \mathrm{M})$ were observed at northern sampling sites associated to the SASW, whereas lower DIN was associated to lower salinity. Concentrations of phosphate $(<0.25 \mu \mathrm{M})$ and silicate $(<0.40 \mu \mathrm{M})$ were, in turn, low and variable over the sampling region (data not shown). A similar nutrient distribution pattern was observed in the summer cruise, although with higher concentrations, reaching up to $4.77 \mu \mathrm{M}$ of DIN, $0.33 \mu \mathrm{M}$ of phosphate and $1.35 \mu \mathrm{M}$ of silicate (see de Souza et al. (2012), for further details). Such spatial gradients in DIN have already been reported for the region in summertime, when higher concentrations of nutrients were associated with a nutrient-enriched SASW, decreasing towards the inner shelf low salinity waters (Balch et al., 2014; Valiadi et al., 2014). Although it has not been measured during our sampling periods, iron could have an important "bottom up" effect on the phytoplankton dynamics across the southern Patagonian sea (Erickson et al., 2003). The N:P and N:Si ratios were not significantly different between spring and summer periods $(\mathrm{p}>0.05)$, and without a clear spatial pattern.
Similar ranges of $\mathrm{N}: \mathrm{P}$ and $\mathrm{N}: \mathrm{Si}$ ratios SAW were reported for the SAW by a study conducted in spring, however further north of our study area, in the Brazil-Malvinas Confluence region (GonçalvesAraujo et al., 2012).

\subsection{Phytoplankton seasonal change}

Recent studies have shown a tight coupling between phytoplankton assemblages and hydrographic conditions within the southern Argentine shelf and shelf-break sectors (Painter et al., 2010; Balch et al., 2014; Valiadi et al., 2014). However, such relationships were only slightly observed in this study, perhaps due to a smaller spatial and time coverage of our sampling program. However, differences in environmental conditions between spring and summer were associated with striking changes in phytoplankton biomass and assemblages over the two sampling periods (see Fig. 3 and Table 5), also captured by the remote sensing time series of both Chl $a$ and calcite (Fig. 5). Thus, it is possible to infer that environmental forcing was mostly driving the seasonal variability of phytoplankton assemblages in the region.

Concerning the phytoplankton community composition, among the spring diatoms, there was an important contribution of Thalassiosira spp. $<20 \mu \mathrm{m}$ (including Thalassiosira oceanica), Eucampia antarctica, Corethron pennatum and Thalassiothrix antarctica. These diatom species are also found in Antarctic waters (Gonçalves-Araujo et al., 2015), indicating that Antarctic and subantarctic communities have an important influence on the southern Patagonian region, through advection of subantactic water from the shelf-break region (Olguín et al., 2006; Olguín and Alder, 2011; Gonçalves-Araujo et al., 2012; Olguín Salinas et al., 2015). Such predominance of diatoms in spring has been described for other domains across the Argentine Sea such as the northern shelf, in the La Plata outflow region (Carreto et al., 2008), shelfbreak (Olguín et al., 2006; Garcia et al., 2008; Segura et al., 2013), farther offshore (Olguín et al., 2006; Olguín Salinas et al., 2015) and in subantarctic waters at the Brazil-Malvinas Confluence (Gonçalves-Araujo et al., 2012). Moreover, it is a tenet of phytoplankton ecology that the dominance of fast growing diatoms in temperate latitudes is mainly related to water column structure, through the establishment of sunlit surface waters containing winter-accumulated nutrients, which triggers massive spring phytoplankton blooms (Sverdrup, 1953). Towards mid- to late summer period, exhaustion of nutrients in strongly stratified water columns hinders phytoplankton growth. However, as stated above, lower nutrient levels were determined in the spring period as compared to summer (see Table 3 ). This indicates that, in spring 
(October 2007), nutrient consumption by a high biomass diatomdominated community led to very low levels of N, P and Si, which must have resulted in growth of small-size phytoplankton groups (coccolithophores and Phaeocystis antarctica) toward summer. Slightly higher nutrient levels observed during the summer cruise might be associated with cross-shelf exchanges and with advection of nutrient-rich waters carried by the Malvinas Current (Matano et al., 2010). In addition, previous studies in the region have demonstrated that occasional strong winds and/or tidal mixing (Glorioso and Flather, 1997; Palma et al., 2004; Romero et al., 2006) may disrupt the pycnocline, allowing some input of nutrients from subjacent layers (Klein and Coste, 1984; Franks and Walstad, 1997). However, the latter is very unlikely to have occurred in our study, given the pronounced stratification observed during our summer cruise. It is known that shallow UMLD (often $<30 \mathrm{~m}$ ), high stability and moderate nutrient (nitrate) concentration are key environmental factors that trigger coccolithophore blooms (Tyrrell and Merico, 2004). Therefore, those conditions (albeit it is not known how long they lasted) were probably favorable to the succession process from diatoms to flagellates, mainly E. huxleyi, as pointed out in de Souza et al. (2012). Furthermore, the high values of the N:Si ratio in spring (although not significantly different from summer) are also an indication of nutrient exhaustion due to high nutrient uptake by diatom blooms, leading to a silicate limitation and consequent depletion of the spring diatom bloom towards summertime.

An ecological feature of the phytoplankton community structure in spring was the abundance of relatively small diatoms ( $\sim 20 \mu \mathrm{m}$, for example Chaetoceros spp. and Thalassiosira spp.) and small flagellates, although the very large diatom Corethron pennatum was the most important species contributing to total phytoplankton carbon biomass (see Table 5). This large species was prominent in deeper UMLD and weaker stratification in spring, which may have kept them in the euphotic layer. That community structure bears resemblance to the transitional phase between early and intermediate stage in phytoplankton succession, i.e., a diatom-dominated phytoplankton biomass with a relative importance of small flagellates (Margalef, 1962). An earlier cruise at the end of summer/beginning of autumn (March 2007) showed a dominance of dinoflagellates (44\% of relative mean contribution) and Phaeocystis antarctica (28\% of relative mean contribution) in the Patagonian shelf-break region (unpublished data), denoting another (later) phase in the phytoplankton succession in the region.

In a synoptic view, a calcite peak and a moderate increase in SSC and POC were observed in December 2007 (see Fig. 5), which likely represented the recurrent early summer development of coccolithophore blooms described in the region, based on calcite satellite compositions (Signorini et al., 2006; Painter et al., 2010; Sadeghi et al., 2012; Balch et al., 2014). Such features suggest that, although calcite concentration has increased approximately 4-fold, indicating the development of a coccolithophore summer bloom, those organisms did not attain much biomass (in comparison to a spring diatom bloom) as expressed by relatively low values of SSC and POC. Our summer cruise coincided with a descending trend in SSC, but high calcite levels (see Fig. 5), when the coccolithophoredominated community was in an advanced stage (de Souza et al., 2012), given the relatively high ratios of PIC:POC (particulate inorganic to organic carbon) and high light backscattering determined in January 2008, associated with presumably large concentrations of detached coccoliths (Garcia et al., 2011).

The diatom assemblages, in spring, were probably under grazing pressure, as indicated by a relatively high proportion of pheopigments $a(14 \%$, on average). In contrast, pheopigment proportions in summer were $<5 \%$. Despite the lack of significant differences in ammonium concentration [as a product of heterotrophic metabolism (Pernthaler, 2005)] between spring and summer ( $p>0.05$, data not shown), highest biomass levels at some sites in spring were associated with higher ammonium concentration (data not shown). These results, thus, reinforce an indication of stronger grazing pressure over the phytoplankton community during the massive spring diatom bloom, in comparison to summer. At the same time, although there is no zooplankton data in this work, our pigment data set offered a way to estimate a trophic link between herbivores, in general, and the whole size-range of the phytoplankton community. In comparison, Sabatini et al. (2012) described a weak match between the mesozooplankton community structure and food patterns and, hence, suggested a poor coupling between consumers and their prey (including phytoplankton) communities at sectors close to our study area, during another spring period. Nonetheless, these authors recognized that sample collection at different daylight hours may have biased their results to some extent. In short we suggest that an important size spectrum of herbivores comprising microand mesozooplankton may have grazed upon the diatom-dominated phytoplankton community in the springtime. Results in this work and evidences from previous studies suggest that striking differences in phytoplankton communities between spring and summer, driven by physical and biological forcing, result in important optical, biogeochemical and trophic implications.

\section{Concluding remarks}

This study conducted in the southern Patagonian shelf contributes to improved understanding of seasonal changes in the phytoplankton community structure associated with changes in environmental conditions. Phytoplankton community dynamics was strongly modulated by variations both in water column structure and nutrients concentration. Both deeper upper mixed layer and less stable pycnocline were marked in the springtime, supporting a high phytoplankton biomass, massively dominated by diatoms. These were associated with lower nutrient levels (especially nitrate and silicate), denoting a high consumption rate. The summer data showed a much stronger pycnocline and shallower UMLD, with moderate levels of nutrients (probably due to lateral advection of nutrient-rich waters from Malvinas Current), coupled with a low biomass associated with the recurrent early summer coccolithophore bloom, as observed from the calcite time series. This flagellate-dominated phytoplankton community was mainly represented by haptophytes (particularly the coccolithophore E. huxleyi and P. antarctica) and dinoflagellates and was in an advanced stage [as stated in Garcia et al. (2011) and de Souza et al. (2012)]. Apart from bottom-up effects, grazing pressure (indicated by degradation Chl $a$ products) also seemed to be important in the modulation of the phytoplankton community in the region.

\section{Acknowledgments}

The authors thank the crew of the Brazilian Navy RV Ary Rongel for their assistance during the field sampling. We also acknowledge the Servicio de Hidrografia Naval (Argentina) for their cooperation in obtaining clearance for carrying out field work within Argentinean EEZ. The cruises 'PATEX IV and V' were conducted under the umbrella of the project 'Southern Ocean Studies for Understanding Climate Changes Issues' (SOS-CLIMATE), a Brazilian contribution to the International Polar Year. Laboratory facilities were provided by the Center of Oceanography of FCUL (Lisbon, Portugal) for HPLC analyses, and by the Laboratório de Fitoplâncton e Microorganismos Marinhos (Institute of Oceanography, 
FURG, Brazil) for microscopic analyses. We are grateful to Simon Wright, from the Australian Antarctic Division, for providing a copy of the CHEMTAX software v.1.95. The authors thank Ricardo C. Pollery for performing the nutrient analysis. This work was supported by financial resources from the Brazilian National Council for Scientific and Technological Development (CNPq, grant 520189/2006-0), the Coordination for Improvement of Higher Level Personnel (CAPES), the Ministry of Science and Technology (MCT) and the Brazilian Ministry of Environment (MMA) to the Brazilian Antarctic Program (PROANTAR). R. Gonçalves-Araujo was funded by an M.Sc. grant from CNPq and is currently funded by a Ph.D. fellowship from CAPES in collaboration with the DAAD (German Academic Exchange Service). M.S. de Souza and C.R. Mendes were granted with Ph.D. fellowships from CAPES. V.M. Tavano is researcher granted with science fellowship from CNPq. M.S. de Souza is now receiving a research fellowship from CAPES.

\section{References}

Acha, E.M., Mianzan, H.W. Guerrero, R.A., Favero, M., Bava, J. 2004 Marine fronts at the continental shelves of austral South America: physical and ecological processes. J. Mar. Syst. 44, 83-105.

Aminot, A., Chaussepied, J., 1983. Manuel dês Analyses Chimiques en Milieu Marin. C.N.E.X.O., Brest.

Balch, W.M., Gordon, H.R., Bowler, B.C., Drapeau, D.T., Booth, E.S., 2005. Calcium carbonate measurements in the surface global ocean based on moderate-resolution imaging spectroradiometer data. J. Geophys. Res. 110, C07001. http: //dx.doi.org/10.1029/2004jc002560.

Balch, W.M., Drapeau, D.T., Bowler, B.C., Lyczkowski, E.R., Lubelczyk, L.C., Painter, S. C., Poulton, A.J., 2014. Surface biological, chemical, and optical properties of the Patagonian shelf coccolithophore bloom, the brightest waters of the Great Calcite Belt. Limnol. Oceanogr. 59, 1715-1732.

Bianchi, A.A., Massonneau, M., Olivera, R.M., 1982. Análisis estadístico de las características T-S del sector austral de la plataforma continental Argentina. Acta Oceanogr. Argent. 3 (1), 93-118.

Bianchi, A.A., Bianucci, L., Piola, A.R., Ruiz Pino, D., Schloss, I., Poisson, A., Balestrini, C.F., 2005. Vertical stratification and air-sea $\mathrm{CO}_{2}$ fluxes in the Patagonian shelf. J. Geophys. Res. 110, 1-10. http://dx.doi.org/10.1029/2004JC002488.

Bianchi, A.A., Ruiz Pino, D., Isbert Perlender, H.G., Osiroff, A.P., Segura, V., Lutz, V.A Luz Clara, M., Balestrini, C.F., Piola, A.R., 2009. Annual balance and seasonal variability of sea-air $\mathrm{CO}_{2}$ fluxes in the Patagonia Sea: their relationship with fronts and chlorophyll distribution. J. Geophys. Res. 114, C03018. http://dx.doi. org/10.1029/2008JC004854.

Carreto, J.I., Montoya, N.G., Benavides, H.R., Guerrero, R., Carignan, M.O., 2003. Characterization of spring phytoplankton communities in the Río de La Plata maritime front using pigment signatures and cell microscopy. Mar. Biol. 143, 1013-1027.

Carreto, J.I., Montoya, N., Akselman, R., Carignan, M.O., Silva, R.I., Cucchi Colleoni, D. A., 2008. Algal pigment patterns and phytoplankton assemblages in different water masses of the Río de la Plat maritime front. Cont. Shelf Res. 28 (13), $1589-1606$

Castro, C.G., Ríos, A.F., Doval, M.D., Pérez, F.F., 2002. Nutrient utilisation and chlorophyll distribution in the Atlantic sector of the Southern Ocean during Austral Summer 1995-96. Deep-Sea Res. II 49, 623-641.

Cousseau, M.B., Perrota, R.G., 2000. Peces marinos de Argentina. Biología, distribución y pesca. INIDEP, Mar del Plata, 167pp.

de Souza, M.S., Mendes, C.R.B., Garcia, V.M.T., Pollery, R., Brotas, V., 2012. Phytoplankton community during a coccolithophore Bloom in the Patagonian shelf: microscopic and high-performance liquid chromatography pigment analyses. Mar. Biol. Assoc. . http://dx.doi.org/10.1017/S0025315411000439

Dodge, J.D., 1982. Marine Dinoflagellates of the British Isles. H.M.S.O., London.

Dogliotti, A.I., Lutz, V.A., Segura, V., 2014. Estimation of primary production in the southern Argentine continental shelf and shelf-break using field and remote sensing data. Remote Sens. Environ. 140, 497-508.

d'Ovidio, F., de Monte, S., Alvain, S., Dandonneau, Y., Lévy, M., 2010. Fluid dynamical niches of phytoplankton types. Proc. Natl. Acad. Sci. USA 107 (43), 18366-18370. http://dx.doi.org/10.1073/pnas.1004620107.

Erickson III, D.J., Hernandez, J.L., Ginoux, P., Gregg, W.W., McClain, C., Christian, J. 2003. Atmospheric iron delivery and surface ocean biological activity in the Southern Ocean and Patagonian region. Geophys. Res. Lett. 30 (12), 1609. http: //dx.doi.org/10.1029/2003GL017241.

El-Sayed, S.Z., 1967. On the productivity of the Southwest Atlantic Ocean and the waters west of the Antarctic Peninsula. In: Schmitt, W., Llano, G.A. (Eds.) Biology of the Antarctic Seas III. Antarctic Research Series 11. American Geophysical Union, Washington, pp. 15-47.

Ferreira, A., Garcia, C.A.E., Dogliotti, A.I., Tavano, V.M., 2013. Bio-optical characteristics of the Patagonia Shelf break waters: Implications for ocean color algorithms. Remote Sens. Environ. 136, 416-432.
Franks, P.J.S., Walstad, L.J., 1997. Phytoplankton patches at fronts: a model of formation and response to transient wind events. J. Mar. Res. 55 (1), 1-29.

Garcia, V.M.T., Garcia, C.A.E., Mata, M.M., Pollery, R.C., Piola, A.R., Signorini, S.R McClain, C.R., Iglesias-Rodriguez, M.D., 2008. Environmental factors controlling the phytoplankton blooms at the Patagonia shelf-break in spring. Deep-Sea Res. I 55, 1150-1166.

Garcia, C.A.E., Garcia, V.M.T., Dogliotti, A.I., Ferreira, A., Romero, S.I., Mannino, A., Souza, M.S., Mata, M.M., 2011. Environmental conditions and bio-optical signature of a coccolithophoid Bloom in the Patagonian shelf. J. Geophys. Res. 116, C03025. http://dx.doi.org/10.1029/2010JC006595.

Glorioso, P.D., Flather, R.A., 1997. The Patagonian Shelf tides. Progr. Oceanogr. 40 263-283.

Glorioso, P.D., 2002. Modelling the South West Atlantic. Aquat. Conserv. 12 (1), 27-37.

Gonçalves-Araujo, R., de Souza, M.S., Mendes, C.R.B., Tavano, V.M., Pollery, R.C. Garcia, C.A.E., 2012. Brazil-Malvinas confluence: effects of environmental variability on phytoplankton community structure. J. Plankton Res. 34 (5), 399-415.

Gonçalves-Araujo, R., de Souza, M.S., Tavano, V.M., Garcia, C.A.E., 2015. Influence of oceanographic features on spatial and interannual variability of phytoplankton in the Bransfield Strait, Antarctica. J. Mar. Syst. 142, 1-15.

Gonzalez-Silvera, A., Santamaria-del-Angel, E., Millán-Núñez, R., 2006. Spatial and temporal variability of the Brazil-Malvinas confluence and the La Plata Plume as seen by SeaWiFS and AVHRR imagery. J. Geophys. Res. 111, C06010. http://dx. doi.org/10.1029/2004JC002745.

Gordon, H.R., Boynton, G.C., Balch, W.M., Groom, S.B., Harbour, D.S., Smyth, T.J 2001. Retrieval of coccolithophore calcite concentration from SeaWiFS imagery. Geophys. Res. Lett. 28 (8), 1587-1590. http://dx.doi.org/10.1029/2000gl012025.

Hasle, G.R., Syvertsen, E.E., 1996. Marine diatoms. In: Tomas, C.R. (Ed.), Identifying Marine Diatoms and Dinoflagellates. Academic Press Inc, London, pp. 5-385.

Jeffrey, S.W., Mantoura, R.F.C., Wright, S.W., 1997. Phytoplankton Pigments in Oceanography: Guidelines to Modern Methods. UNESCO, Paris.

Klein, P., Coste, B., 1984. Effects of wind-stress variability on nutrient transport into the mixed layer. Deep-Sea Res. Part A 31 (1), 21-37.

Lund, J.W.G., Kipling, C., Le Cren, E.D., 1958. The inverted microscope method of estimating algal numbers and the statistical basis of estimations by counting Hydrobiologia 11 (2), 143-170.

Lutz, V.A., Segura, V., Dogliotti, A.I., Gagliardini, D.A., Bianchi, A.A., Balestrini, C.F., 2010. Primary production in the Argetine Sea during spring estimated by field and satellite models. J. Plankton Res. 32 (2), 181-195.

Mackey, M.D., Mackey, D.J., Higgins, H.W., Wright, S.W., 1996. CHEMTAX—a program for estimating class abundances from chemical markers: application to HPLC measurements of phytoplankton. Mar. Ecol. Prog. Ser. 144, 265-283.

Margalef, R., 1962. Succession in marine populations. Adv. Front. Plant Sci., 2137-2188.

Matano, R.P., Palma, E.D., Piola, A.R., 2010. The influence of the Brazil and Malvinas currents on the Southwestern Atlantic shelf circulation. Ocean Sci. 6, 983-995.

Menden-Deuer, S., Lessard, E.J., 2000. Carbon to volume relationships for dinoflagellates, diatoms, and other protist plankton. Limnol. Oceanogr. 45 (3) 569-579.

Mendes, C.R., Cartaxana, P., Brotas, V., 2007. HPLC determination of phytoplankton and microphytobenthos pigments: comparing resolution and sensitivity of a $\mathrm{C}_{18}$ and a $\mathrm{C}_{8}$ method. Limnol. Oceanogr.: Methods 5, 363-370.

Mendes, C.R.B., de Souza, M.S., Garcia, V.M.T., Leal, M.C., Brotas, V., Garcia, C.A.E., 2012. Dynamics of phytoplankton communities during late summer around the tip of the Antarctic Peninsula. Deep-Sea Res. I 65, 1-14.

Mitchell, B.G., Holm-Hansen, O., 1991. Observations and modelling of the Antarctic phytoplankton crop in relation to mixing depth. Deep-Sea Res. II 38, 981-1007.

Möller, O.O., Piola, A.R., Freitas, A.C., Campos, E.J.D., 2008. The effects of river discharge and seasonal winds on the shelf off southeastern South America. Cont. Shelf Res. 28, 1607-1624.

Montagnes, D.J.S., Berges, J.A., Harrison, P.J., Taylor, F.J.R., 1994. Estimating carbon, nitrogen, protein, and chlorophyll a from volume in marine phytoplankton. Limnol. Oceanogr. 39 (5), 1044-1060.

Olguín, H.F., Boltovskoy, D., Lange, C.B., Brandini, F., 2006. Distribution of spring phytoplankton (mainly diatoms) in the upper $50 \mathrm{~m}$ of the Southwestern Atlantic Ocean (30-61오 $)$. J. Plankton Res. 28 (12), 1107-1128.

Olguín, H.F., Alder, V.A., 2011. Species composition and biogeography of diatoms in antarctic and subantarctic (Argentine shelf) waters (37-76 $\mathrm{S}$ ). Deep-Sea Res. II 58, 139-152.

Olguín Salinas, H.F., Brandini, F., Boltovskoy, D., 2015. Latitudinal patterns and interannual variations of spring phytoplankton in relation to hydrographic conditions of the southwestern Atlantic Ocean (34-62 $\left.{ }^{\circ} \mathrm{S}\right)$. Helgol. Mar. Res. . http: //dx.doi.org/10.1007/s10152-015-0427-6

Painter, S.C., Poulton, A.J., Allen, J.T., Pidcock, R., Balch, W.M., 2010. The COPAS'08 expedition to the Patagonian Shelf: Physical and environmental conditions during the 2008 coccolithophore bloom. Cont. Shelf Res. 30, 1907-1923.

Palma, E.D., Matano, R.P., Piola, A.R., 2004. A numerical study of the Southwestern Atlantic Shelf circulation: barotropic response to tidal and wind forcing. J. Geophys. Res., 109. http://dx.doi.org/10.1029/2004JC002315.

Paparazzo, F.E., 2011. Distribucion espacio-temporal de nutrientes en el Mar Argentino, Passaje Drake y Península Antártica. Tasa de incorporación por fitoplancton. Universidad de Buenos Aires, Argentina, p. 171.

Paparazzo, F.E., Bianucci, L., Schloss, I.R., Almandoz, G.O., Solís, M., Esteves, J.L., 2010. Cross-frontal distribution of inorganic nutrients and chlorophyll- $a$ on the Patagonian continental shelf of Argentina during summer and fall. Rev. Biol. Mar. 
Oceanogr. 45 (1), 107-119.

Pernthaler, J., 2005. Predation on prokaryotes in the water column and its ecological implications. Nat. Rev. Microbiol. 3, 537-546.

Putt, M., Stoecker, D.K., 1989. An experimentally determined carbon: volume rati for marine oligotrichous ciliates from estuarine and coastal waters. Limnol. Oceanogr. 34 (6), 1097-1103.

Rivas, A.L., Dogliotti, A.I., Gagliardini, D.A., 2006. Seasonal variability in satellitemeasured surface chlorophyll in the Patagonian shelf. Cont. Shelf Res. 26 (6) 703-720.

Romero, S.I., Piola, A.R., Charo, M., Garcia, C.A.E., 2006. Chlorophyll-a variability off Patagonian based on SeaWiFS data. J. Geophys. Res., 111. http://dx.doi.org/ 10.1029/2005JC003244.

Sabatini, M.E., Ramírez, F.C., Martos, P., 2000. Distribution pattern and population structure of Calanus australis Brodsky, 1959 over the southern Patagonian Shelf off Argentina in summer. ICES J. Mar. Sci. 57 (6), 1856-1866.

Sabatini, M., Reta, R., Matano, R., 2004. Circulation and zooplankton biomass distribution over the southern Patagonian shelf during late summer. Cont. Shelf Res. 24 (12), 1359-1373.

Sabatini, M.E., Akselman, R., Reta, R., Negri, R.M., Lutz, V.A., Silva, R.I., Segura, V., Gil, M.N., Santinelli, N.H., Sastre, A.V., Daponte, M.C., Antacli, J.C., 2012. Spring plankton communities in the southern Patagonian shelf: hydrography, mesozooplankton patterns and trophic relationships. J. Mar. Syst. 94, 33-51.

Sadeghi, A., Dinter, T., Vountas, M., Taylor, B., Altenburg-Soppa, M., Bracher, A. 2012. Remote sensing of coccolithophore blooms in selected oceanic regions using the PhytoDOAS method applied to hyper-spectral satellite data. Biogeosciences 9, 2127-2143.

Schloss, I.R., Ferreyra, G.A., Ferrario, M.E., Almandoz, G.O., Codina, R., Bianchi, A.A. Balestrini, C.F., Ochoa, H.A., Pino, D.R., Poisson, A., 2007. Role of plankton communities in sea-air variations in $\mathrm{pCO}_{2}$ in the SW Atlantic Ocean. Mar. Ecol. Prog. Ser. 332, 93-106.

Segura, V., Lutz, V.A., Dogliotti, A., Silva, R.I., Negri, R.M., Akselman, R., Benavides, H., 2013. Phytoplankton types and primary production in the Argentine Sea. Mar. Ecol. Prog. Ser. 491, 15-31.

Signorini, S.R., Garcia, V.M.T., Piola, A.R., Garcia, C.A.E., Mata, M.M., McClain, C.R. 2006. Seasonal and interannual variability of calcite in the vicinity of the Patagonian Shelf Break ( $\left.38^{\circ} \mathrm{S}-52^{\circ} \mathrm{S}\right)$. Geophys. Res. Lett. 33. http://dx.doi.org/ 10.1029/2006GL026592 (L1,6610).

Sournia, A., 1978. Phytoplankton Manual. UNESCO, Muséum National d'Histoire Naturelle, Paris.

Stramski, D., Reynolds, R.A., Babin, M., Kaczmarek, S., Lewis, M.R., Röttegers, R.,
Sciandra, A., Stramska, M., Twardowski, M.S., Franz, B.A., Claustre, H., 2008. Relationships between the surface concentrations of particulate organic carbon and optical properties in the eastern South Pacific and eastern Atlantic Oceans. Biogeosciences 5, 171-201. http://dx.doi.org/10.5194/bg-5-171-2008.

Sverdrup, H.U., 1953. On conditions for the vernal blooming of phytoplankton.

Conseil Permanent International pour L'Exploration de la Mer, 18, pp. 287-295.

Takahashi, T., Sutherland, S.C., Wanninkhof, R., Sweeney, C., Feely, R.A., Chipman, D. W., Hales, B., Friederich, G., Chavez, F., Sabine, C., Watson, A., Bakker, D.C.E., Schuster, U., Metzi, N., Yoshikawa-Inoue, H., Ishii, M., Midorikawa, T., Nojiiri, Y., Körtzinger, A., Steinhoff, T., Hoppema, M., Olafsson, J., Arnarson, T.S., Tilbrook, B., Johannessen, T., Olsen, A., Bellerby, R., Wong, C.S., Delille, B., Bates, N.R., de Baar, H.J.W., 2009. Climatological mean and decadal change in surface ocean $\mathrm{pCO}_{2}$, and net sea-air $\mathrm{CO}_{2}$ flux over the global oceans. Deep-Sea Res. II 56, 554-577.

ter Braak, C.J.F., 1994. Canonical community ordination Part I. Basic theory and linear methods. Ecoscience 1, 127-140.

ter Braak, C.J.F., Prentice, I.C., 1988. A theory of gradient analysis. Adv. Ecol. Res. 18, 271-317.

Tyrrell, T., Merico, A., 2004. Emiliania huxleyi: bloom observations and the conditions that induce them. In: Thierstein, H.R., Young, J.R. (Eds.), Coccolithophores: From Molecular Processes to Global Impact. Springer, Berlin, pp. 75-97.

Utermöhl, H., 1958. Zur Vervollkommnung der quantitativen Phytoplankton. Methodik Mitt Int Ver Limnol., 9, pp. 1-38.

Valiadi, M., Painter, S.C., Allen, J.T., Balch, W.M., Iglesias-Rodriguez, M.D., 2014. Molecular detection of bioluminescent dinoflagellates in surface waters of the Patagonian shelf during early Austral summer 2008. PLoS One 9 (6), e98849. http://dx.doi.org/10.1371/journal.pone.0098849.

Verity, P.G., Robertson, C.Y., Tronzo, C.R., Andrews, M.G., Nelson, J.R., Sieracki, M.E., 1992. Relationships between cell volume and the carbon and nitrogen content of marine photosynthetic nanoplankton. Limnol. Oceanogr. 37 (7), 1434-1446.

Werdell, P.J., Bailey, S.W., 2005. An improved bio-optical data set for ocean color algorithm development and satellite data product validation. Remote Sens. Environ. 98, 122-140. http://dx.doi.org/10.1016/j.rse.2005.07.001.

Wright, S.W., Ishikawa, A., Marchant, H.J., Davidson, A.T., van den Enden, R.L., Nash, G.V., 2009. Composition and significance of picophytoplankton in Antarctic waters. Pol. Biol. 32 (5), 797-808.

Zapata, M., Rodríguez, F., Garrido, J.L., 2000. Separation of chlorophylls and carotenoids from marine phytoplankton: a new HPLC method using a reversed phase $C_{8}$ column and pyridine-containing mobile phases. Mar. Ecol. Progr. Ser. 195, 29-45. 